\title{
Meningococcemia: rare but life-threatening
}

\author{
Inês Medeiros, ${ }^{1}$ Ana Reis Melo, ${ }^{2}$ Vera Baptista, ${ }^{1}$ Augusto Ribeiro ${ }^{3}$
}

'Pediatrics, Hospital de Braga,

Braga, Portugal

${ }^{2}$ Pediatrics, Centro Hospitalar de São João, Porto, Portugal

${ }^{3}$ Pediatric Intensive Care, Centro Hospitalar de São João, Porto, Portugal

\section{Correspondence to}

Dr Inês Medeiros,

inesdemedeiros@hotmail.com

Accepted 27 September 2018

\section{DESCRIPTION}

A previously healthy 5 -month old girl, presented at the emergency department with high fever $\left(40^{\circ} \mathrm{C}\right)$, vomiting and nasal congestion. She had no abnormalities on physical exam and was discharged home with diagnosis of a probable viral infection, after excluding urinary infection.

Ten hours later, the infant was readmitted with purpuric lesions and prostration (figure 1), rapidly presenting with labial cyanosis, capillary refill of $6 \mathrm{~s}$, tachycardia, hypotension and anuria (cold shock). The patient was empirically treated with ceftriaxone and vancomycin, started inotropic and ventilator support, having been transferred to a hospital with a paediatric intensive care unit with a refractory shock, purpuric rash and disseminated intravascular coagulation (figure 2 ).

Blood workout revealed leucopenia $\left(2.600 / \mathrm{mm}^{3}\right)$ with neutropenia $\left(2.00 / \mathrm{mm}^{3}\right), \mathrm{C}$ reactive protein $89 \mathrm{mg} / \mathrm{L}$, urea nitrogen $30 \mathrm{mg} / \mathrm{dL}$, creatinine $0.8 \mathrm{mg} /$ $\mathrm{dL}$ and a metabolic acidosis ( $\mathrm{pH} 7.176, \mathrm{pCO}_{2} 29.3 \mathrm{~mm}$ $\mathrm{Hg}, \mathrm{HCO}_{3} 10.6 \mathrm{mmol} / \mathrm{L}$, lactates $5 \mathrm{mmol} / \mathrm{L}$ ). Volume expansion and transfusion of multiple blood components were needed and inotropic support was adjusted to epinephrine, norepinephrine and milrinone. In the first 24 hours, she presented with renal insufficiency with anasarca and continuous venovenous haemodiafiltration $(\mathrm{CVVH})$ was initiated.

The child progressively started to improve, maintaining CVVH for 7 days, and ventilatory and inotropic support for 10 days. Thoracic and abdominal cutaneous haemorrhagic lesions improved, but haemorrhagic lesions of the extremities evolved to necrosis with need of hands and feet amputation. Neisseria meningitidis serogroup B was isolated on blood cultures. Currently, at the age of 7 months, the infant is still in the surgery ward for skin grafting. She

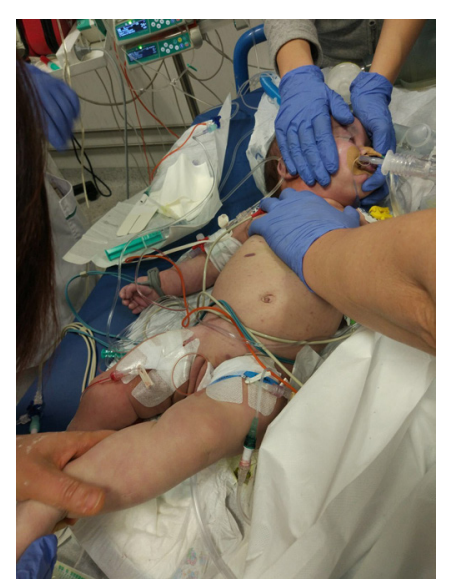

Figure 1 Petechiae and purpuric lesions only on the thoracoabdominal region.

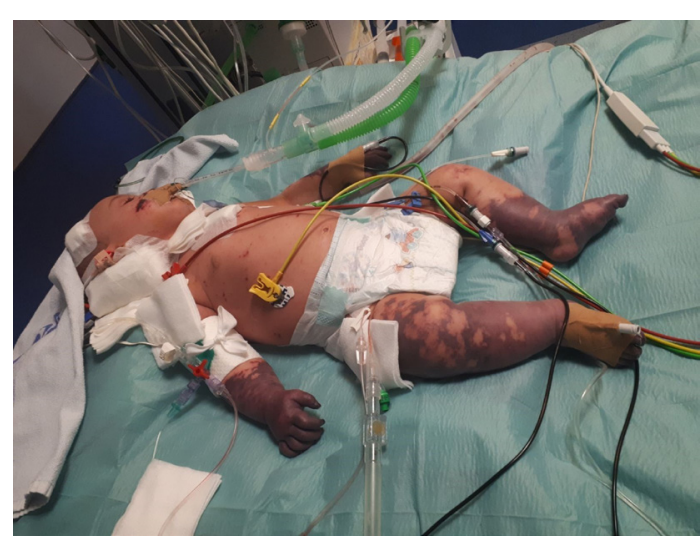

Figure 2 Purpura fulminans with necrosis of extremities.

has an unremarkable neurological exam, with normal cerebral MRI.

N. meningitidis is a Gram-negative bacteria that can be highly pathogenic in humans, the only host. Since 2008, the European incidence rate of meningococcal disease is $0.68 / 100000$, with the highest cases among children younger than 5 years. ${ }^{1}$ Concerning invasive disease, serogroup B is the most common, followed by serogroup C. In these cases, early antibiotics, aggressive initial shock approach and precocious referral to intensive care are potential factors with impact on reducing its mortality. ${ }^{23}$

The Portuguese immunisation programme only covers the serogroup $\mathrm{C}$ but vaccine for serogroup $\mathrm{B}$ (MenB), although expensive, is available for purchase.

\section{Learning points}

- Meningococcal infection, although rare, has high mortality and severe morbidity in children, heightening the importance of preventing this invasive disease.

- Nowadays serogroup B is the main meningococcal disease-causing agent, so immunisation with the MenB conjugate vaccine should be recommended and included in national infant immunisation programmes.

- Early and correct intervention with antibiotics and supportive care can be life-saving in fulminant meningococcaemia.

Contributors IM wrote the manuscript and reviewed the literature. ARM reviewed the literature. VB corrected the manuscript. $A R$ corrected the final revision of the manuscript.

Funding The authors have not declared a specific grant for this research from any funding agency in the public, commercial or not-for-profit sectors.

Competing interests None declared.

Patient consent Parental/guardian consent obtained. 
Provenance and peer review Not commissioned; externally peer reviewed.

\section{REFERENCES}

1 Gabutti G, Stefanati A, Kuhdari P. Epidemiology of Neisseria meningitidis infections: case distribution by age and relevance of carriage. J Prev Med Hyg 2015;56:E116-E120.
2 Huang HR, Chen HL, Chu SM. Clinical spectrum of meningococcal infection in infants younger than six months of age. Chang Gung Med J 2006;29:107-13.

3 Villena R, González J. [Meningococcal invasive disease caused by serogroup B in two Chilean children vaccinated against ACWY serogroups]. Rev Chilena Infectol 2016;33:700-2.

Copyright 2018 BMJ Publishing Group. All rights reserved. For permission to reuse any of this content visit

http://group.bmj.com/group/rights-licensing/permissions.

BMJ Case Report Fellows may re-use this article for personal use and teaching without any further permission.

Become a Fellow of BMJ Case Reports today and you can:

- Submit as many cases as you like

- Enjoy fast sympathetic peer review and rapid publication of accepted articles

- Access all the published articles

- Re-use any of the published material for personal use and teaching without further permission

For information on Institutional Fellowships contact consortiasales@bmjgroup.com

Visit casereports.bmj.com for more articles like this and to become a Fellow 